\title{
Theoretical Framework of Human Capital Development of SMEs: The Context of an ERP Project
}

\author{
Balla Diop, Daniel Pascot and Sidi Mahmoud Aidara Mbibi
}

Département des systèmes d'information organisationnels, Université Laval, Canada

Correspondence should be addressed to: Balla Diop; balla.diop@fsa.ulaval.ca

Received 6 March 2012; Accepted 28 May 2013; Published 28 November 2013

Copyright (C) 2013 Balla Diop, Daniel Pascot and Sidi Mahmoud Aidara Mbibi. Distributed under Creative Commons CC-BY 3.0

\begin{abstract}
ERP systems are increasingly adopted by SMEs. The ERP system is one of the more complex information systems to implement and its failure rate remains high despite the accumulated experiences. Its implementation indeed requires a large amount of knowledge and technical expertise and skills. Therefore, to facilitate access to the knowledge and expertise that have external partners, SMEs implanting ERP weave social relations (i.e. social conduits) with these external partners. Social conduits allow the transfer knowledge and sharing of expertise. The woven relations represent a social capital for the SMEs and enable them to develop their own technical knowledge, skills and experience (before the withdrawal of external partners). These intangible resources developed represent their human capital. This paper proposes, from the existing literature, a theoretical framework in which are represented the potential factors that can impact on the development of human capital. This paper is a theoretical research which contributes to the literature by showing the existence of an effect (direct and indirect) of social capital on human capital development of SMEs in the implementation ERP project. Regarding practical implications, the framework identified in this research can help the manager of SMEs to increase the likelihood of successful implementation of ERP systems.
\end{abstract}

Keywords: ERP, human capital, social capital, transfer and integration of knowledge, absorptive capacity, SMEs.

\section{Introduction}

Nowadays, the enterprises, whether they are small or medium-sized business (S.M.B) or large enterprises, are overwhelmed with information on their customers, products, employees and other assets (namely, information on transactions of purchase and sale) (Serrano and Sarriegi, 2006). Beyond the challenge of the management of the large volume of information, they are also exposed to other challenges from the pressure of their external business environment that is more and more uncertain and very competitive. (Mabert et al., 2003; Lengnick-hall et al., 2004; Mabert et al., 2000). As a fact, the necessity of an information system equipped with an appropriated computing kernel becomes absolutely essential for the survival and the organizational competitiveness of the enterprises as well. To face, the troubles of this environment and the limits of their existing systems shaped as silos, many enterprises change their strategy of information system (IS) by 
adapting an integrated software packages like an Enterprise Resource Planning (ERP). An ERP system is a set of software modules, each of which covers a specific functional perimeter while sharing a single common database (Xiu et al., 2005). It is a suite of software that integrate all the information flow and the business process of an enterprise (Lengnick-hall and Lengnick-hall, 2006). Therefore, the ERP systems are designed to integrate and optimize the organizational business process (Motwani et al., 2005). They are technological innovations of type III - that is to say the ERP systems belong to the most complex systems to be implemented and their implementation requires a high level of knowledge, skills and technical expertise (Shiau et al., 2009; Swanson, 1994) at the implementation phase and the post-implementation phase as well (Stratman and Roth, 2007). In fact, " ERP implementation is a knowledge intensive process; it requires a great deal of experience from many different stakeholders, and requires these individuals to interact extensively during the implementation process " (Wang et al., 2007: pg. 201). It seems that any customer enterprise possesses all the internal and required knowledge and competences to implement an ERP system by itself. To implement an ERP system, the enterprises have to resort to the external resources of knowledge, meaningly the consultants, integrators and editor (Newell et al., 2004; Jones, 2005; Serrano and Sarriage, 2006; Tim Brell and Gable, 2001; Wang et al., 2007). In general, every enterprise that implements an ERP system collaborates with or uses the external sources of knowledge that have "the pivotal knowledge" (McGinnis and Huang, 2007) to maximize the chances of the project success. This collaboration is, most often, through relations (social) linking the client enterprise and external sources of knowledge. In literature, it is sustained that the social relations are social canals of knowledge (i.e. transfer/transmission canals of knowledge flow (Szulanski, 1996; Tsai and Goshal, 1998; Tsai, 2002). Therefore, the established social relations between the different participants and the contents that are inside the network constitute a capital-key organizational resource-for the enterprise that undertakes an ERP implementation project. Literature names it the social capital. The social capital allows taking or acquiring knowledge resources that possess the external partners (consultants and editor) (Yli-Renko et al., 2001, Pan et al., 2007; Newell et al., 2006). Therefore, the social relations established by the enterprise during an ERP project with the external sources of knowledge are essential for access to knowledge and technical competences. Contrary to large enterprises, the SMEs have more problems with the complex information system implementation considering the financial and intellectual resources constraints on side to which they are subject and, on the other side, their dependence on the external enterprise (Thong et al., 1994). It is obvious that the stakes in the relations with the external partners are more critical for the SMEs than the large enterprise. In this research, we mainly focus on the issues related to the development of human capital for SMEs, during an ERP project, because these issues are very important in the contexts of SME due to their constraining characteristics of their organizational and environmental contexts (Raymond and Blili, 2005).

Literature about the ERP systems in the context of SMEs is not so abundant compared to the existing literature in the context of large enterprises. Among the rare researches that have studied the impact of the social capital in the ERP system context, we can highlight the qualitative studies of Newell et al. (2004), of Pan et al (2007), Newell et al (2006) and the theoretical research of Lengnick-hall et al (2004). However, the existing literature on the ERP systems has never dealt with the question of human capital development in a SME context. However, to succeed well the ERP system implementation as well as their evolution, the SMEs have to develop technical knowledge and skills in order to be able to configure and adapt their ERP system as long as the organizational business process change. 
This paper is a theoretical research whose main goal is to erect a theoretical framework from literature in order to provide a better understanding of the various factors involved in the process of the human capital development (i.e. the development of knowledge, skills and experiences) in an ERP project. Through this theoretical framework, the authors have identified some propositions allowing managers, who are conscious of the importance of the human capital development, to better establish their decisions surrounding their strategies for sustainable development of human capital in an ERP system context. The human capital development (i.e. the development of technical knowledge and skills, experiences) is indeed crucial for the successful implementation of the ERP system and its evolution during the postimplantation.

\section{ERP System Implementation and Human Capital Development}

\section{Diffusion and Use of ERP Systems in SMEs}

Nowadays, we face a growing diffusion and adoption of ERP systems within the SMEs. Many reasons can explain this adoption phenomenon of ERP systems by SMEs: (1) the emergence of lighter versions of ERP systems (i.e. easy to configure and a lower price) created specifically for SMEs like ASAP ("Accelerated SAP") (Sledgianowski et al., 2007; Timbrell and Gable,2002); (2) the market saturation of large enterprises causing the rush of major ERP systems editors to the SMEs market; (3) the appearance of open source ERP systems created by the open source communities. This trend concerning the rapid diffusion of ERP systems in SMEs can be also explained by their need to reinforce their business position as well as improving and strengthening their competitive capacity. In fact, environmental pressures make that many SMEs are changing their information systems (IS) by adopting an integrated an ERP systems (Esteves, 2009; Park et al., 2007). Many of them choose to implement an ERP system to improve their organizational performance by improving and increasing their level of competitiveness and efficiency (Shian et al., 2009; Esteves, 2009; Hong and Kim, 2002)

\section{ERP System: A Complex System Requiring a Large Amount of Technical Knowledge and Skills}

Literature supports that the ERP system is a complex system (Okali and Oh, 2007; Li et al., 2006; Lengnick-hall et al., 2004; Pan et al., 2007; Dong- Gil et al., 2005; Soh et al., 2000). An ERP system is not only an integrated and personalized application, but an organizational infrastructure that affects the employees' method of work and imposes its own logic to managers when defining the organizational strategies. An ERP system is a complex information system because it has an impact on the main dimensions of the enterprise management: the culture, the organizational structure, the roles and responsibilities, the information processing and flow, the process of work, the interpersonal interactions, the design of the relations between the employees in other words the social system of the organization (Li et al., 2006; Lengnick-hall et al., 2004; Pan et al., 2007). Consequently, the ERP system shapes all aspects of the organization. Therefore, the ERP system has significant implications that go beyond the issues of operational efficiency (Lengnick-Hall et al., 2004). This complexity of the ERP system comes from the transversal modules of the ERP system, from the standardization of the business process of the system over the whole functions of the enterprise. This makes the ERP system implementation a complex and difficult exercise (Motwani et al., 2005) which requires a large amount of technical knowledge and skills, in other words, a sufficient level of human capital.

\section{Human Capital}

In literature, there are several definitions of human capital. According to Nahapiet and Ghoshal (1998), human capital refers to accessible and acquired knowledge, skills and abilities that allow the employees to react in another way. Cabrera and 
Cabrera (2005) say that "human capital refers to the skills and the abilities of individual or the stock of knowledge within an organization" (pg.720). The human capital refers to the tacit knowledge and skills that reside in the mind of the enterprise employees and managers (Esteves, 2009; Chen and Shih, 2009). According to $\mathrm{Wu}$ et al (2007), the human capital is the accumulation of investments in human resources in terms of education and training, etc. According to Coleman (1998), the human capital includes all the knowledge and skills acquired that allow the human resources (i.e. employees) to act in new ways. According to Lengnick-Hall and Lengnick-Hall "Human capital is the knowledge, skills, abilities and experience unique to each individual employee. The collective human capital of all; of a firm's employees forms a unique intangible resource that distinguishes it from other organizations and provides the basis for strategic capability" (p.186). Bontis (1998) defined the human capital as a component of intellectual capital. In fact, according to Bontis, every employee is a node that represents a human capital for the organization and that the essence of the human capital is even the intelligence of the organization members. Effectively, the human capital of an organization is the aggregate sum of the intelligence of its employees. The employees or nodes are linked by social ties. These social ties are social conduits for the information flows and the sum of these represents the social capital (Bontis, 1998). This is corroborated by Tsai and Ghoshal (1998) who argue that "social ties are channels for information and resources flows" (pg. 467), showing then the close relationship between the social capital and the human capital. According to Bontis (1998), the social links (i.e. the social relations) allow the employees to share their intelligence (i.e. their informational resources like their knowledge, skills, etc.). The sharing information resource among employees increases the level of human capital organizational. More there are nodes in a social network of the organization and more the quantity of the flows of information and knowledge accessible is high in the sense that there would be more social connections between nodes (i.e. between human capital) and more social interactions (i.e. more exchanges). In this sense, Tsai and Goshal (1998) argue that "through social interactions an actor may gain access to other actors' resources" (pg. 467). According to Coleman, the difference between the human capital and the social capital is that the human capital refers to competences and knowledge acquired by an individual whereas the social capital shows the relations between the individuals.

One of the particularities of the human capital is that, nowadays, one of the most important organizational resources. Several authors consider, the human capital, as a strategic resource. Just like physical capital and social capital, human capital can facilitate productive activities (Coleman, 1988). Cabrera and Cabrera (2005) sustain that the human capital is vital for the success of an organization. According to these authors, each organization must develop its own human capital to support the development of its sustainable competitive advantage. This statement is confirmed by Lepak and Snell (1999) who consider human capital as a crucial organizational resource to the organization. According to Cabrera and Cabrera (2005); "human capital is necessary for achieving a competitive advantage" (pg. 720). In this same vein, Hayes (2003) argues that "the best resource to grow any business is human capital" (pg.45). In the same perspective, Bontis (1998) argues that 'human capital is important; it is a source of innovation and strategic renewal [...]" (pg. 65).

Despite its potential benefits, the human capital is a degradable resource that demands long-term organizational policies to maintain an acceptable level. According to Bontis (1998); "a stock of human capital will deteriorate if not constantly supported and nurtured" (p. 17). Effectively, the stock of the human capital can deteriorate or become obsolete if it is not constantly sustained and developed by organization. Therefore, if the human capital is the level of the accessible and acquired intellectual 
resources (i.e. knowledge, skills and experience) then its deterioration may be caused by the decrease of intellectual resources acquired or by the loss of access to the intellectual resources available, particularly during the implementation process of an ERP system.

\section{ERP System Implementation: A Process of the Human Capital Development}

An ERP system is a technological innovation of type IIIc, that is to say one of the most complex systems to implement and evolve. Then, it requires a considerable technical expertise (Shiau et al., 2009). The implementation of an innovation type IIIc as the implementation of an ERP system is an intensive process of knowledge and skills transfer (Swanson, 1994). Its implementation requires many experiences in the field of IT and the organizations management as well as varied competences in matter of technological system integration. This explains the reason for the presence and the intervention of multiple stakeholders, both internal and external participants (Wang et al., 2007; Pan et al., 2007) for the implementation of this kind of technological innovation. Lee and Lee (2000) note, for this purpose, the existence of many ways of analyzing the ERP system implementation: 1-the perspective of the diffusion/ adoption; 2-the perspective of reengineering business process. At this respect, an ERP system implementation can be analyzed as a process of information system implementation or as a process of creation, storage and transfer of knowledge and skills (Li et al., 2006). According to Soh et al (2000), the knowledge transfer is important for the success of an ERP system project. The ERP system implementation requires, in fact, a transfer of business knowledge embedded in the ERP system to the SMEs (Lee and Lee, 2000). According to Wang et al (2007); " an ERP system is an enterprise-wide and complicated system, requiring a certain level of competence or capabilities to deal with the challenges imposed during the implementation process" (p.204). The success of the implementation and the evolution of the
ERP system depend, consequently, on the technical competences developed by the SME. Bessant and Rush (1995) note that the building of technological skills for an enterprise is dependent on external knowledge sources (i.e. the support and the assistance from external partners) to which the enterprise resorts to acquire knowledge and to develop skills necessary to the success of ERP project. The acquisition of these appropriated informational resources supports the development of the competitive advantage.

According to Lengnick-hall et al (2004) "[...] significant early investments are needed to have the in-house expertise needed to modify ERP when an unexpected market jolt or organizational breakthrough occurs" (pg. 312). These expertise and technological skills developed internally and representing the stock of human capital of the enterprise reflect the technological capability of the enterprise to maintain and make evolve its own ERP system dictated by the business environment. The development capacity refers to the organization capacity of adapting to the environmental changes (Motwani et al., 2005). According to Stratman and Roth (2007); "since ERP systems operate in a dynamic business environment, they must adapt to changes in the strategic and operational focus of the firm" (pg. 611). In the ERP system context, the capacity of evolution referring to the ability to adapt and to parameterize an ERP system reflects the organizational human capital (i.e. the stock of skills and technical knowledge of the ERP system).

According to Baldwin and Johnson (1995), the human capital development strengthens the technological capacity of the enterprise. Cabrera and Cabrera (2005) note that the human capital is a source of competitive advantage. In an ERP system context, the human capital related to the implemented system reflects the technological capacity of an enterprise to maintain and manage the ERP system, in other words, the ability to transform or change the ERP system of the enterprise. According to Lengnick-Hall and Lengnick- 
Hall (2006); "to develop a competitive advantage from ERP implementation, organization needs a deep reservoir of talent" (pg. 186). In line with this, Lengnick-Hall et al (2004) report that according to Porter the competitive advantage needs a distinctive asymmetry of resources between enterprises. The competitiveness of enterprises having the same technological tools (i.e. the same ERP system) cannot reside on the technological artifact (Kumar et al., 2003), but rather on the difference of their technological capacity and their capacity to change their system. In other words, the competitiveness of enterprises having the same technological tools resides on the difference on the level of their human capital. However, knowing that the human capital is an erosive resource, that is to say a resource that deteriorates over time in the absence of long-term development (Bontis, 1998), the difference of the competitiveness between the enterprises having the same ERP systems is located on the difference from their capacity of developing the human capital over time. As we mentioned above, Cabrera and Cabrera (2005) sustain that "human capital is necessary for achieving a competitive advantage" (pg.720). From what precedes, we can advance the following proposals.

Proposition $1\left(\mathbf{P}_{\mathbf{1}}\right)$ : In the context of ERP, a SME that constantly develops its human capital during the phases of implementation and post-implementation strengthens more its competitive advantage in comparison with the one that less or does not develop it.

Proposition $2\left(\mathbf{P}_{2}\right)$ : In the context of ERP, an SME that constantly develops its human capital during the phases of implementation and post-implementation strengthens more its productivity in comparison with the one that less or does not develop it.

\section{The Social Capital Effects on the Human Capital Development in an ERP System}

\section{General Effect of Social Capital}

Literature on the social capital argues that the social capital can contribute, in many ways to the accomplishment of some activities or expectation in organizational or entrepreneurial order. In this regard, the social capital is a key factor to the intellectual capital development of an enterprise (Nahapiet and Ghoshal, 1998; Lengnick-Hall et al., 2004); to the capacities development or the learning process (DeWever, 2008); to the human capital development (Coleman, 1988); to the knowledge acquisition and exploitation process (Tsai, 2002; Sapario and Gopalakrishman,2009); to the development of free software (Okali and Oh, 2007); to the innovation and creation of added value (Tsai and Ghoshal, 1998); to the performance of R\&D (Lee et al., 2005); to the achievement of the new enterprises and the entrepreneurial activities (Batjargal, 2007); to obtain a job or a key position (Kamanzi, 2006). The concept "social capital" has therefore been studied from many different angles (i.e. perspectives) and fields. Research on social capital has been particularly intensive in many fields (namely, the fields of management and economic, etc) and especially in the sociology field (ValintinoCouros 2006). Moreover, it has become the central concept in entrepreneurship research (Ikeda, 2008; Batjargal, 2007). The studies from these fields of research constitute an excellent starting point for our research that aims to develop a theoretical framework that conceptualizes the human capital development in the context of SMEs planning to begin the projects of ERP system implementation. However, few researches have tried to study the social capital effect (i.e. the social relation network) in the context of an ERP system implementation (Newell et al., 2004; Pan et al., 2007; Newell et al., 2006; Wang et al, 2007) regarding the transfer and integration of knowledge. In addition, no research has yet thought about the direct or indirect effect of the social capital on the human capital development of SMEs having implemented ERP systems.

Knowing that the success of an ERP system widely depends on acquired and accessible knowledge, skills and experiences, in other words on the developed and accessible human capital of the SME. Social relations 
allows SMEs to access the accessible human capital, in other words, to be able to transfer the technical knowledge of external sources of knowledge (i.e. editor and integrators) to its employees through social relations (i.e. social conduits of knowledge).Therefore, studying the link between the social capital and the human capital development would become, according to us, an important research in the field of research in information systems (IS).

The social capital being not a monolithic entity (Valentino-Couros, 2006; Newell et al., 2004; Tsai and Ghoshal, 1998) it is conceptualized in several manners or forms: the private social capital or public social capital; the formal social network or informal social network; the external social relations ( i.e. the bridging ties) or the internal social relations (i.e. bonding ties); the strong social ties or the weak social ties; the density; the diversity of social relations; the culture; the degree of centrality in the network; the friendship degree, etc. (Valintino-Couros, 2006; Okali and Oh, 2007; Wan Aken and Weggeman, 2000; Li and Li, 2007).

Therefore, the social capital comprises the internal social relations (i.e. bonding ties) and the external social relations (i.e. bridging ties) of a collectivity (Pan et al., 2007). Moreover, it refers to the internal and external social structure, mainly to the social relation structures of a collectivity (Pan et al., 2007). Maintaining social relations strengthens the social capital and ensures an internal cohesion that allows the collectivity to carry out or realize common objectives (or interests) (Pan et al., 2007). According to Newell et al (2006), the social capital derives from the social relations network between actors in the network. The central proposition of the social capital theory sustains that social networks that, as the social relations networks, constitute invaluable resources to carry out business because the social ties allow the network members to have access to the capital (or resource) belonging to the collectivity (Bourdieu 1986, quoted in Nahapiet and Ghoshal, 1998). The implementation of an ERP system can be considered as an intensive process of transfer of knowledge flow, both of explicit and tacit knowledge. Therefore, the implementation of an ERP system is a process of the human capital development. The transfer of knowledge flows being a social phenomenon (Saparito and Gopalakrishman, 2009); consequently, the human capital development is a social phenomenon.

In this study, we have adopted the definition of Nahapiet and Ghoshal (1998) that operationalizes the concept of social capital in terms of dimensions (or resources) main: (1) the structural social capital; (2) the relational social capital; (3) the cognitive social capital. The structural social capital refers to the social ties between individuals and social groups as well as their configuration and complexity. The structure of social relations represents the structural dimension of the social capital. Nahapiet and Ghoshal argue that the advantages of a social network are often acquired through the understanding and optimization of the social relations. The structural dimension of the social capital refers to the configuration of the social ties (i.e. the pattern of social relations or the architectural of social connections) (Lee et al., 2005). The relational social capital refers to all qualitative aspects associated of a social network. The relation social capital is the personal dimension of the social relations in a social network. The relational dimension describes the relations nature between members of a social network like the quality of the social relations, the level of trust between the network members, the degree of friendship, the degree of formalization of social relations, the depth of social interactions, etc. (Lee et al., 2005). Finally, the cognitive social capital represents all the network resources that allow a common or shared building of knowledge, some representations or schemes of references (Lee et al., 2005) between the members of the social network. A common understanding between the members of the social network can facilitate the communication, 
which, at its turn, makes easy the sharing and exchanges of resources between the network members.

\section{Direct Effect of the Social Capital on the Human Capital Development during an ERP Project}

Yli-Renko et al (2001) note that the capacity of creating a competitive advantage for an enterprise does not only depends on the enterprise resources but, it also depends on the social relations established with its external partners by allowing the enterprise to acquire all the resources (such as knowledge and the competences) appropriated for its evolution. The social relations constituting the social capital allow an organization to tap or acquire resources of knowledge that its external partners have at their disposal (consultants and publisher) (Yli-Renko et al., 2001). Most of enterprises have not all internal knowledge and skills necessary to implement an ERP system. SMEs implementing an ERP systems make use of external knowledge sources (i.e. external partners as editor and knowledge integrators) to fill their knowledge in order to successfully carry out their project (Newell et al., 2004, Jones, 2005; Serrano and Sarriegi, 2006; Timbrell and Gable, 2002; Dong-Gil et al., 2005). The networking, or in other words, the extension or the development of the social capital is very important for enterprises, especially SMEs, that implement complex systems of type IIIc such as the ERP systems requiring specialized and precise expertise and large volumes of knowledge and skills during the implementation phase as well as during the post-implantation phase. The importance of networking for the team responsible for the ERP system implementation is raised, many times, in the literature. In this perspective, Pan et al (2007) argue "the ERP project team will need to network among themselves and other stakeholders to make sense of both organizational processes (current and potential) and the ERP system" (pg. 407). Networking allows the team members to have access to the other external knowledge in order to share with team members. According to Lengnick-Hall and
Lengnick-Hall (2006), the social capital is an intangible organizational resource like the human capital and is based on the structure and content of the social relations. As we have mentioned, SMEs have not, in house, all the sufficient knowledge and competences to implement a complex information system, as the ERP systems, without resorting to external knowledge partners which are their external knowledge sources (Newell et al., 2004; Jones, 2005; Serrano and Sarriegi, 2006). These knowledge sources are consultants or integrators and editors that represent the main basins of knowledge and skills from where SMEs implementing ERP systems rely to acquire and develop the knowledge and skills. This choice of external knowledge partners to weave collaborative social relations implicitly implies a choice of strategy to extend social relations of SME (i.e. to expand its own network or social capital) in order to benefit and access to resources within the new social network. According to Newell et al (2004); "project team members [...] need to mobilize their social capital in order to access distributed knowledge about organizational processes" (p.546). In their study about the integration and the knowledge sharing in a context of an ERP system implementation, Newell et al (2004) find that the enterprises having widen their social capital by creating communities online (like an intranet) have better succeeded their integration and sharing knowledge process comparing to the others. In an ERP system implementation context, these same authors found that the external social ties (i.e. bridging ties) are more important in the knowledge integration process than the internal ties between the members (i.e. bonding ties). According to Newell et al (2004), the bonding ties are rather important for the cohesion of the team members.

On the basis of a systematic review on the SMEs development, Macpherson and Robin (2006) note that the human capital and the social capital are among the main emergent themes. The capitalization of the intellectual resources that are in a SME social network is necessary for the 
reinforcement of its human capital (Macpherson and Robin, 2006). This human capital reinforcement is necessary for the SME having ERP systems because the human capital is the foundation of the SME's ability of development. However, the development of the organizational human capital depends on the learning capacity. In this same line, De-Wever (2008) argues that the capacity development and the organizational learning process are, in fact, influenced by the three dimensions of the social capital: the relational dimension, the structural dimension and the cognitive dimension. Consequently, the social capital is a decisive factor of capacity of development this one being defined as the whole knowledge, experiences, and technical skills necessary for the development of human capital.

Proposition $3\left(\mathbf{P}_{3}\right)$ : In the context of an ERP system project, a SME that develops its social capital (structural, relational and cognitive), during the implementation and post-implementation phase, will have more opportunities to develop its human capital comparing with the one that less or does not develop it.

\section{Indirect Effect of Social Capital on the Human Capital Development during an ERP Project}

\section{$\underline{\text { Knowledge Transfer and Integration }}$}

By studying the role of the social capital on the challenges associated to the knowledge sharing and integration during an ERP project, Pan et al (2007) found that the need to share knowledge and acquire new knowledge and skills goes beyond the implementation phase. This need is also felt during the post-implementation phase. In addition, these authors found that the external social ties ('bridging ties") and the internal social ties (that is "bounding ties') are very important in a project of an ERP system implementation but their effects vary according to the project phases. The success of the interactive innovation projects, such as the implementation project of complex system type ERP, is strongly dependent on the network activities of the team members in charged to implement the ERP system (Newell et al., 2004). Networking allows the members of the team to overcome the challenges of sharing and integrating knowledge to which the team charged to implement ERP systems face. Chen and Shih (2009), for their part, have studied the role of the three aspects of the intellectual capital-human capital, organizational capital and relational capital-on knowledge transfer. Through a quantitative approach, Chen and Shih (2009) found that the intellectual capital has an effect on the knowledge transfer. In other words, the human capital, the relational capital and organizational capital have directly or indirectly impacted on the performance of knowledge transfer. During this study, Chen and Shih (2009) have also found that the relational capital plays a mediating role on the relation between the human capital and the achievement of knowledge transfer as well as between the organizational capital and the performance of knowledge transfer. Therefore, the reinforcement of the relational capital (i.e. the development of the social capital) allows an enterprise to better strengthen and make more successful its transfer activities of knowledge flow. Chen and Shih's (2009) results sustain that the relational capital is social conduct necessary to strengthen organizational performance. These results show the critical roles of the relational capital for enterprises involved in knowledge transfer activities. In this same vein, Gupta and Govindarajan (2009) argue that the capacity of knowledge transfer of a social network depends on transmission channels (i.e. social relations of the network). Therefore, the social capital has a positive impact on the adoption process of an ERP system (Pan et al., 2007). In sum, the social capital is as well important and vital during the implementation phase as during the post-implementation phase. In this line, Pan et al (2007) argue that "[...] in the context of an ERP project, social capital is, thus, a vital ingredient to facilitate the access and integration of knowledge that is needed for designing and implementing an ERP system" (pg. 229). In particular, more the access and integration of the 
knowledge of external sources are easy for the SME implementing an ERP system, and, the more easily it will be able to develop its skills, knowledge, and technical experiences (i.e. its human capital) through social interactions with the external sources of knowledge. Thus, we can state the following propositions:

Proposition $4\left(\mathbf{P}_{4}\right)$ : In the context of an ERP system, a SME that develops more its social capital (i.e. structural, relational and cognitive capital) will have more opportunities for knowledge transfer and integration comparing to the one that less or does not develop it.

Proposition $5\left(\mathbf{P}_{5}\right)$ : In the context of an ERP system, a SME that more easily transfer and integrate the technical knowledge from external sources (i.e. editors or integrators) will more easily to develop its human capital comparing to the one that has difficulties to access, transfer and integration of technical knowledge from external sources.

\section{Absorption Capacity}

The notion of absorption capacity has been the subject of many researches for several disciplines. Cohen and Levinthal (1990) define the absorption capacity as the ability of an organization to recognize the relevance of a piece of information, to assimilate and exploit it for commercial purposes. The concept of the absorption capacity is operationalized by Zahra and George (2002) by the knowledge acquisition, assimilation, transformation and exploitation. In an ERP project, there are a lot of knowledge flowing between the different network actors (i.e between the SME undertaking the implementation project of an ERP system and the external partners). The SME must develop its absorption capacity in order to be able to absorb maximum of technical knowledge before the withdrawal of external partners in order to be able to manage, maintain and make evolve its ERP system in the future.

Literature highlights the importance of the absorption capacity in the transfer and exploitation of knowledge flows (Minbaeva et al., 2003; Dong-Gil et al., 2005; Szulanski, 1996). Minbaeva et al (2003) have found a significant positive relation between the absorption capacity and the knowledge transfer process between 169 multinational subsidiaries. They sustain that large organization must put good practices of human resources management to reinforce their absorption capacity that is important for the knowledge transfer process between the different subsidiaries/unities of an organization. In this regard, Wang et al (2007) argue that "firms differ in their capability to absorb and assimilate new inputs of the ERP system" (p.210). These authors are finding that the skills of the consultants and absorption capacity of the client are important in the transfer of knowledge. The customer's capacity in the knowledge transfer process to acquire, assimilate and exploit the knowledge is; in particular, represent its capacity to absorb knowledge flows coming from external sources of knowledge. Kwark and Shym (2006) have, on their part, studied the role of human capital as a key factor impacting on the ability of absorption of foreign technology of a nation. These authors have found that the human capital is a main factor on the capacity to absorb developed foreign technologies. Through a quantitative approach, Szulanski (1996) has found that there are three significant barriers to knowledge transfer flows between the recipient and the source of knowledge. Among these barriers, there is the lack of absorptive capacity of the recipient. Absorptive capacity of an organization is in fact dependent on the volume flow of knowledge organization accessible, transferable and exploitable by the organization. Considering that a network volume of knowledge is influenced by the social capital - relational, structural and cognitive - whereas the social capital is an important factor in the development of the absorptive capacity of an organization in a project implementation of an ERP system. We can, thus, advance the following propositions:

Proposition $6\left(\mathbf{P}_{\mathbf{6}}\right)$ : During an ERP system project, a SME that more develops its social capital (structural, relational and cognitive) 
will have more opportunities to develop its absorptive capacity compared to the one that less or does not develop it.

Proposition $7\left(\mathbf{P}_{7}\right)$ : During an ERP system project, a SME that more easily transfers and integrates technical knowledge from external sources will have more volume of knowledge to absorb (i.e. more opportunities to develop its capacity to absorb) comparing to the one that has more transfer and access barriers (i.e. less knowledge to absorb).

The whole propositions put forward in the framework of this research has allowed elaborate the theoretical framework for the development of the human capital during an ERP system project. The theoretical framework of the figure 1 postulates that the social capital, the knowledge transfer and integration as well as the absorption capacity of these ones have direct effects on the capital development during an ERP system project. The setting postulates also the existence of an indirect effect of the knowledge transfer and integration on the human capital through the absorption capacity as well as the existence of an indirect effect of the absorption capacity on the human capital through the knowledge integration and transfer.

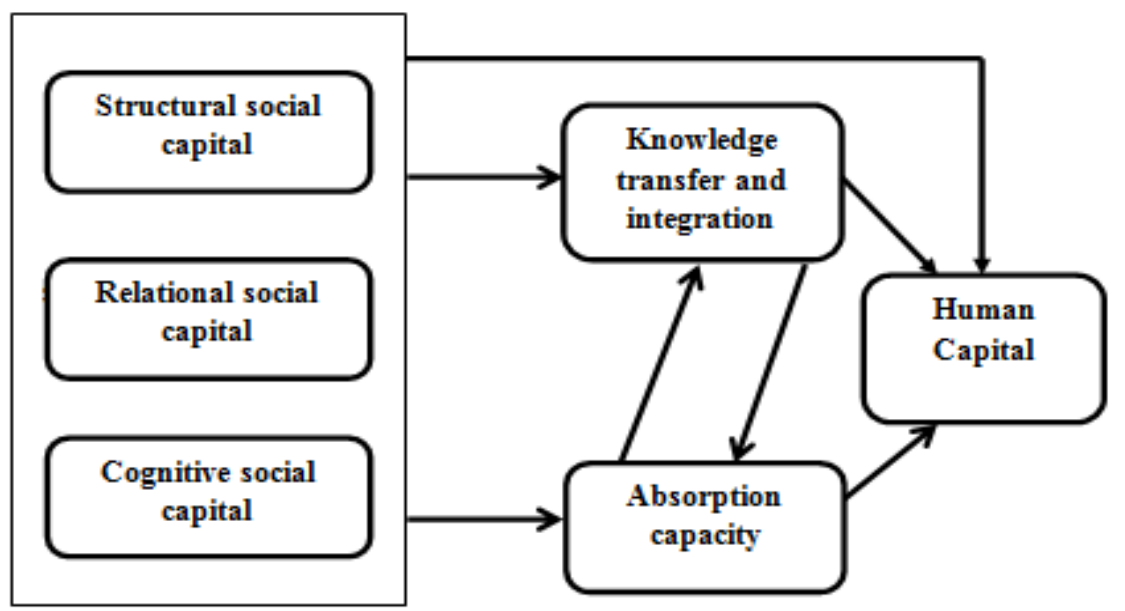

Figure 1: Conceptual Framework for the Development of Human Capital

\section{Conclusion}

The ERP system is one of the most complex applications to implement and make evolve. Its implementation is an intensive process of knowledge transfer and demands many technical competences and expertise for the parameterization and reconciliation of the system logic and the organizational logic during the implementation and post-implementation phases. Considering the volume of expertise, knowledge and required technical competences, every SME that undertakes an ERP system implementation project must collaborate or build social relations with external partners of knowledge (editors and consultants/integrators).

These established social relations constitute, on the one hand, the social capital and, on the other hand, are social canals allowing the knowledge transfer. They support the human capital development. The development of the social capital allows reducing the structural, relational and cognitive obstacles that is the obstacle of human capital development.

By exploiting the existing literature we have built a theoretical framework showing the main factors that can have potential impacts on the human capital development during an ERP project in a SME context. Many propositions have been done to show the direct effect of social 
capital on the human capital development. This theoretical framework shows us also the indirect effect of the social capital on the human capital development through two factors: the absorption capacity and the knowledge integration and transfer. Thus, the SMEs implementing an ERP system should imperatively work to develop and widen their social relations with the external sources of knowledge (i.e. to expand or develop their social capital) to have a better position to develop their human capital, which, according to Hayes, is a source of competitive advantage.

Several studies emphasize the role of the social capital in the development of human capital (Coleman, 1988; Macpherson and Robin, 2006; De-Wever, 2008) and the intellectual capital (Bontis, 1998; Lee et al., 2005; Lengnick-Hall et al., 2004; Nahapiet and Goshal, 1998; Newell et al., 2006; Pan et al., 2007). This theoretical study corroborates and contributes to the existing literature by making a theoretical framework that shows the direct and indirect effect of the social capital in the development of the human capital of a SME during an implementing project of an ERP system. The theoretical framework could be empirically experienced in future research.

\section{References}

Batjargal, B. (2007). "Internet Entrepreneurship: Social Capital, Human Capital, and Performance of Internet Ventures in China," Research Policy, 36 (5): pg. 605-618.

Bessant, J. \& Rush, H. (1995). "Building Bridges for Innovation: The Role of Consultants in Technology Transfer," Research Policy, 24 (1): pg. 97-114.

Bontis, N. (1998). "Intellectual capital: An Exploratory Study that Develops Measures and Models," Management Decision, 36 (2): pg. 63-76.

Cabrera, E. F. \& Cabrera, A. (2005). "Fostering Knowledge Sharing through People Management Practices," The
International Journal of Human Resource Management, 16 (5): pg. 720-735.

Chen, C.- J., Shih, H.- A. \& Yang, S.- Y. (2009). "The Role of Intellectual Capital in Knowledge Transfer," IEEE Transaction of Engineering Management, 56 (3): pg. 402411.

Coleman, J. S. (1988). "Social Capital in the Creation of Human Capital," The American Journal of Sociology, Vol. 94 (s1), pg. s95s120.

Cohen, W. M. \& Levinthal, D. A. (1990). "Absorptive Capacity: A New Perspective on Learning and Innovation," Administrative Science Quarterly, 35(1), p. 128-152.

De-Wever, S. (2008). "Learning and Capability Development: The Impact of Social Capital," Advances in Applied Business Strategy, 10: pg. 121-157.

Esteves, J. (2009). “A Benefits Realisation Road-Map Framework for ERP Usage in Small and Medium-Sized Enterprises," Journal of Enterprise Information Management, Vol. 22 (1/2), pg. 25-35.

Hayes, M. (2003). 'Niche Development Tips: CPAs with Strong Service Specialties Share Some Details about How to Make Them Grow,' Journal of Accountancy, Vol. 196 (6), pg. 45-54.

Hong, K.- K. \& Kim, Y.- G. (2002). "The Critical Success Factors for ERP Implementation: An Organizational Fit Perspective," Information \& Management, Vol. 40 (1), pg. 25-40.

Ikeda, S. (2008). "The Meaning of Social Capital as it Relates to the Market Process," The Review of Austrian Economy, Vol. 21 (2), pg. 127-182.

Jones, M. C. (2005). "Tacit Knowledge Sharing During ERP Implementation: A Multi-Site Case Study," Information Resources Management Journal, Vol. 18 (2), pg. 1-23. 
Kamanzi, P. C. (2006). "Influence du Capital Humain et du Capital Social sur les Caractéristiques de l'emploi chez les Diplômés Postsecondaires au Canada," Université Laval, Thèse de doctorat en sociologie.

Ko, D.- G., Kirsch, L. J. \& King, W. R. (2005). "Antecedents of Knowledge Transfer from Consultants to Clients in Enterprise System Implementations," MIS Quarterly, Vol. 29 (1), pg. $59-85$.

Kumar, V., Maheshwari, B. \& Kumar, U. (2003). "An Investigation of Critical Management Issues in ERP Implementation: Empirical Evidence from Canadian Organizations," Technovation, Vol. 23 (10), pg. 793-807.

Kwark, N.- S. \& Shyn, Y.- S. (2006). "International R\&D Spillovers Revisited: Human Capital as an Absorptive Capacity for Foreign Technology," International Economic Journal, Vol. 20(2), pg. 179-196.

Lee, Z. \& Lee, J. (2000). “An ERP Implementation Case Study from a Knowledge Transfer Perspective," Journal of Information Technology, Vol. 15(4), pg. 281-288.

Lengnick-Hall, C.- A., Lengnick-Hall, M. L. \& Abdinnour-Helm, S. (2004). "The Role of Social and Intellectual Capital in Achieving competitive Advantage through Enterprise Resource Planning (ERP) Systems," Journal of Engineering and Technology Management, Vol. 21 (4), pg. 307-330.

Lepak, D.- P. \& Snell, S.- A. (1999). "The Human Resource Architecture: Toward a Theory of Human Capital Allocation and Development," Academy of Management Review,Vol. 24 (1), pg. 31-48.

Li, Y., Liao, X. W. \& Lei, H. Z. (2006). “A Knowledge Management System for ERP Implementation," Systems Research and Behavioral Science, Vol. 23(2), pg. 157-168.

Mabert, V. A., Soni, A. \& Venkataramanan, M. A. (2000). "Enterprise Resource Planning Survey of U.S. Manufacturing
Firms," Production and Inventory Management Journal,Vol. 41 (2), pg. 52-58.

Mabert, V. A., Soni, A. \& Venkataramanan, M. A. (2003). "The Impact of Organization Size on Enterprise Resource planning (ERP) Implementation in the US Manufacturing Sectors," The International Journal of Management Science, Vol. 31 (3), pg. 235-246.

Macpherson, A. \& Holt, R. (2007). "Knowledge, Learning and Small Firm Growth: A Systematic Review of the Evidence," Research Policy, Vol. 36, Iss. 2, pg. 172-192.

McGinnis, T. C. \& Huang, Z. (2007). "Rethinking ERP Success: A New Perspective from Knowledge Management and Continuous Improvement," Information and Management, Vol. 44 (7), pg. 626-634.

Minbaeva, D., Pedersen, T., Bjorkman, I., Fey, C. F. \& Park, H. J. (2003). "MNC Knowledge Transfer, Subsidiary Absorptive Capacity, and HRM," Journal of International Business Studies, Vol. 34 (6), pg. 586-599.

Motwani, J., Subramanian, R. \& Gopalakrishna, P. (2005). "Critical Factors for Successful ERP Implementation: Exploratory Findings from Four Case Studies," Computers in Industry, Vol. 56 (6), pg. 529-544.

Nahapiet, J. \& Ghoshal, S. (1998). "Social Capital, Intellectual Capital, and the Organizational Advantage," The academy of Management Review, Vol. 23 (2), pg. 242266.

Newell, S., Huang, J. \& Transley, C. (2006). "ERP Implementation: A Knowledge Integration Challenge for the Project Team," Knowledge and Process Management, Vol. 13 (4), pg. 227-238.

Newell, S., Tansley, C. \& Huang, J. (2004). "Social Capital and Knowledge Integration in an ERP Project Team: The Importance of 
Bridging AND Bonding," British Journal of Management, Vol. 15 (1), pg. 43-57.

Okoli, C. \& Oh, W. (2007). "Investigating Recognition-based Performance in an Open Content Community: A Social Capital Perspective," Information and Management, Vol. 44 (3), pg. 240-252.

Pan, S. L., Newell, S., Huang, J. \& Galliers, R. D. (2007). "Overcoming Knowledge Management Challenges during ERP Implementation: The Need to Integrate and Share Different Types of Knowledge," Journal of the American Society for Information Science and Technology, Vol. 58 (3), pg. 404-419.

Park, J.- H., Suh, H.- J. \& Yang, H.- D. (2007). "Perceived Absorptive Capacity of Individual Users in Performance of Enterprise Resource Planning (ERP) Usage: The Case for Korean Firms," Information and Management, Vol. 44 (3), pg. 300-312.

Raymond, L. \& Blili, S. (2005). 'Les Systèmes d'information,' In P. -A. Julien (dir.), La PME. Bilan et perspectives (p. 419-457). Cap-Rouge: Presses Interuniversitaire.

Saparito, P. A. \& Gopalakrishnan, S. (2009). "The Influence of Communication Richness, Self-Interest, and Relational Trust on Banks' Knowledge about Firms within the Small-Cap Debt Finance Markets," IEEE Transactions on Engineering Management, Vol. 56(3), pg. 436-447.

Serrano, N. \& Sarriegi, J. M. (2006). “Open Source Software ERPs: A New Alternative for an Old Need," IEEE, Vol. 23 (3), pg. 9497.

Shiau, W.- L., Hsu, P.- Y. \& Wang, J.- Z. (2009). "Development of Measures to Assess the ERP Adoption of Small and Medium Enterprises," Journal of Enterprise Information Management, Vol. 22 (1/2), pg. 99- 118 .

Sledgianowski, D., Tafti, M. H. A. \& Kierstead, J. (2007). "SME ERP System Sourcing Strategies: A Case Study,"
Industrial Management \& Data Systems, Vol. 108 (4), pg. 421-436.

Soh, C., Kien, S. S. \& Tay-Yap, J. (2000). "Cultural Fits and Misfits: Is ERP a Universal Solution?," Communications of the ACM, Vol. 43 (4), pg. 47-51.

Stehr, N. (1994). Knowledge Societies, Sage Thousand Oaks, Calif.

Stratman, J. K. \& Roth, A. V. (2007). "Enterprise Resource Planning (ERP) Competence Constructs: Two-stage MultiItem Scale Development and Validation," Decision sciences, Vol. 33 (4), pg. 601-628.

Swanson, E. B. (1994). "Information System Innovation among Organizations," Management Science, Vol. 40 (9), pg. 10691092.

Szulanski, G. (1996). "Exploring Internal Stickness: Impediments to the Transfer of Best Practice within the Firm," Strategic Management Journal, Vol. 17 (winter), pg. 27-43.

Szulanski, G. (2000). "The Process of Knowledge Transfer: A Diachronic Analysis of Stickiness," Organisational Behavior and Human Decision Processes, Vol. 82 (1), pg. 9-27.

Thong, J. Y. L., Yap, C.- S. \& Raman, K. S. (1994). "Engagement of External Expertise in Information Systems Implementation," Journal of Management Information Systems, Vol. 11 (2), pg. 209 - 231.

Timbrell, G. G. \& Gable, G. T. (2001). "The SAP Ecosystem: A Knowledge Perspective," In Proceedings 12th Information Resources Management Association International Conference: Managing information technology in a global environment, pages pp. 1115-1118, Toronto, Canada.

Tsai, W. (2002). "Social Structure of "Coopetition" Within a Multiunit Organization: Coordination, Competition, and Intraorganizational Knowledge Sharing," Organization Science, Vol. 13 (2), pg. 179-190. 
Tsai, W. \& Goshal, S. (1998). “Social Capital and Value Creation: The Role of Intrafirm Networks," Academy of Management Journal, Vol. 41(4), pg. 464-476.

Valintino-Couros, A. (2006). "Examining the Open Movement: Possibilities and Implications for Education," University of Régina, thèse de doctorat.

Van Aken, J. E. \& Weggeman, M. P. (2000). "Managing Learning in Informal Innovation Networks: Overcoming the Daphnedilemma," R\&D Management, Vol. 30 (2), pg. 139-149.

Van den Hooff, B. \& De Winter, M. (2011). "Us and Them: A Social Capital Perspective on the Relationship between the Business and IT Departments," European Journal of Information Systems, 20, 255-266

Wang, E., Ying, T.- C., Jiang, J. \& Klein, G. (2007). 'Group Cohesion in Organizational Innovation: An Empirical Examination of ERP Implementation,' International Journal of Information Management, 27 (3):200212.

Wu, C.- G., Gerlach, J. H. \& Young, C. E. (2007). "An Empirical Analysis of Open Source Software Developers' Motivations and Continuance Intentions," Information \& Management, Vol. 44 (3), pg. 253-262.

Xue, Y., Liang, H., Boulton, W. R. \& Snyder, C. A. (2005). "ERP Implementation Failures in China: Case Studies with Implications for ERP Vendors," International Journal of Production Economics, Vol. 97 (3), pg. 279 295.

Yli-Renko, H., Autio, E. \& Sapienza, H. J. (2001). "Social Capital, Knowledge Acquisition, and Knowledge Exploitation in Young Technology-Based Firms," Strategic Management Journal, Vol. 22 (6), pg. 587613.

Zahra, S., A. \& George, G. (2002). "Absorptive Capacity: A Review, Reconceptualization, and Extension," The Academy of Management Review, 27(2), p. 185-200. 